\title{
IGF2BP3 Autoantibody
}

National Cancer Institute

\section{Source}

National Cancer Institute. IGF2BP3 Autoantibody. NCI Thesaurus. Code C123807.

An autoantibody that recognizes insulin-like growth factor 2 mRNA-binding protein 3. 